\title{
Suppression of Metalloproteinase Biosynthesis in Human Alveolar Macrophages by Interleukin-4
}

\author{
Sylvie Lacraz, Laurent Nicod, * Beatrice Galve-de Rochemonteix, Christophe Baumberger, \\ Jean-Michel Dayer, and Howard G. Welgus* \\ Immunology and Allergy Division and the *Respiratory Division, Department of Medicine, Hôpital Cantonal Universitaire, \\ Geneva, Switzerland; and Division of Dermatology, Department of Medicine, Jewish Hospital \\ at Washington University Medical Center, St. Louis, Missouri 63110
}

\begin{abstract}
To study the interaction of lymphocytes and macrophages in the control of extracellular matrix turnover, we determined the effects of several soluble $T$ cell products on mononuclear phagocyte production of metalloproteinases. Cytokines including IL2, IL-4, IL-6, tumor necrosis factor $\alpha$ (TNF $\alpha$ ), GM-CSF, and IFN-gamma were each tested for capacity to modulate macrophage metalloproteinase and tissue inhibitor of metalloproteinases (TIMP) expression. The addition of IL-4 to cells cultured under basal conditions caused a dose-dependent suppression in the release of $92-\mathrm{kD}$ type IV collagenase without affecting TIMP production. 92-kD enzyme secretion was inhibited by $50 \%$ with 1-2 $\mathrm{ng} / \mathrm{ml}$ of IL-4 and by $90 \%$ with $10 \mathrm{ng} / \mathrm{ml}$ of IL-4. When cells were first exposed to killed Staphylococcus aureus to induce metalloproteinase production, IL-4 potently blocked the stimulated release of both interstitial collagenase and 92 $k D$ type IV collagenase, again without effect upon TIMP. Metabolic labeling experiments and Northern hybridizations demonstrated that IL-4 exerted its action at a pretranslational level. Furthermore, IL-4 possessed the capacity to inhibit metalloproteinase expression even in the relatively immature peripheral blood monocyte. As reported previously (Shapiro, S. D., E. J. Campbell, D. K. Kobayashi, and H. G. Welgus. 1990. J. Clin. Invest. 86:1204), IFN-gamma suppressed constitutive macrophage production of $92-\mathrm{kD}$ type IV collagenase. Despite the frequent antagonism observed between IL-4 and IFNgamma in other systems, the combination of these two agents lowered metalloproteinase biosynthesis dramatically, whereas IL-4 opposed the IFN-gamma-stimulated production of cytokines (IL-1 and TNF $\alpha$ ). IL-6 had only minimal effect upon metalloproteinase production, but appeared to specifically augment TIMP release. In summary, cytokines released by activated $T$ cells may profoundly reduce the capacity of the macrophage to mediate extracellular matrix degradation. (J. Clin. Invest. 1992. 90:382-388.) Key words: metalloproteinases • collagenase $\bullet$ macrophage $\bullet$ cytokines
\end{abstract}

\section{Introduction}

Mononuclear phagocytes are developmentally complex cells that subserve a variety of immunoregulatory, phagocytic, and

Address correspondence to Howard G. Welgus, M.D., Division of Dermatology, Jewish Hospital at Washington University Medical Center, 216 South Kingshighway, St. Louis, MO 63110.

Received for publication 23 January 1992 and in revised form 18 March 1992.

J. Clin. Invest.

(c) The American Society for Clinical Investigation, Inc.

0021-9738/92/08/0382/07 \$2.00

Volume 90, August 1992, 382-388 secretory functions. Macrophages can modulate the turnover of extracellular matrix both directly by producing metalloproteinases and proteinase inhibitors $(1,2)$ and also indirectly by secretion of IL-1 (3) and tumor necrosis factor (TNF) ${ }^{1}(4)$, soluble messengers that potently induce metalloproteinase gene expression by resident tissue fibroblasts. The capacity of macrophages to remodel extracellular matrix can in turn be influenced by other cell types such as the activated $\mathrm{T}$ lymphocyte, especially at sites of inflammation. In this regard, we have shown that very low concentrations $(10-40 \mathrm{U} / \mathrm{ml})$ of the lymphokine IFN-gamma abolish interstitial collagenase and stromelysin production by human alveolar macrophages ( 5 ), even while this factor serves to upregulate most other macrophage functions including tumoricidal capacity $(6,7)$.

The production of metalloproteinases and tissue inhibitor of metalloproteinases (TIMP) by mononuclear phagocytes has been the subject of several recent reports $(2,8,9)$. As such cells undergo differentiation from monocytes into resident tissue macrophages, their proteinase armamentarium shifts from an intracellularly stored group of neutrophil-like serine enzymes into a highly regulatable, but secreted battery of metalloproteinases $(2,8,10)$. Two major secreted macrophage metalloenzymes are $92-\mathrm{kD}$ type IV collagenase and interstitial collagenase $(1,2,11)$. Production of the $92-\mathrm{kD}$ enzyme is characterized by $(a)$ secretion at a relatively early stage of cell differentiation (2); $(b)$ high basal levels of expression (11); and (c) catalytic function that appears to replace the highly related $72-\mathrm{kD}$ type IV collagenase released by fibroblasts $(11,12)$. The $92-\mathrm{kD}$ enzyme can cleave a broad spectrum of extracellular matrix substrates that includes native types IV and V collagens, denatured collagens, fibronectin, and insoluble elastin (13, 14). This latter specificity may provide a link between the massive proliferation of macrophages and abnormal elastolysis found in smoker's emphysema. Catalytic activity of 92-kD type IV collagenase is controlled by the simultaneously secreted counterregulatory molecule TIMP. The potential physiological importance of macrophage metalloproteinase production is underscored by recent in situ hybridization studies demonstrating high levels of stromelysin mRNA in lipid-laden macrophages of atherosclerotic plaques (15) and of interstitial collagenase mRNA in macrophage-like cells of the rheumatoid synovial pannus (16).

IL-4 is a $20-\mathrm{kD}$ glycoprotein produced by activated T cells that influences many biological functions. Originally isolated based on its capacity to induce proliferation of B cells costimulated with anti-IgM antibodies (17), it is now recognized that

1. Abbreviations used in this paper: $\mathrm{k} S$. aureus, killed Staphylococcus aureus; TIMP, tissue inhibitor of metalloproteinases; TNF, tumor necrosis factor. 
IL-4 also modulates B cell antibody isotype expression (18), T cell activation (19), mast cell proliferation (20), and hematopoiesis (21). As regards the mononuclear phagocyte, IL-4 can exert profound effects that have either activating or suppressing properties. For example, the lymphokine accelerates monocyte-macrophage cell differentiation in vitro (22) and enhances MHC class II antigen expression (22) while inhibiting secretion of IL-1 $\beta$, TNF $\alpha$, and IL-6 $(23,24)$ and also blocking osteoclast formation from progenitor mononuclear phagocytes (25). Furthermore, considerable evidence has accumulated to suggest that IL-4 antagonizes many of the activities of the cosecreted lymphokine IFN-gamma $(26,27)$. Since we have previously reported the suppressive effects of IFN-gamma on macrophage metalloproteinase expression (5), we embarked upon the present study to assess the potential of IL- 4 to modulate metalloenzyme production by the human alveolar macrophage. Our results indicate that IL-4 potently inhibits macrophage capacity for interstitial collagenase and $92-\mathrm{kD}$ type IV collagenase release without altering TIMP secretion. Furthermore, IFN- $\gamma$ potentiates the ability of IL- 4 to suppress metalloproteinase biosynthetic capacity whereas it antagonizes the inhibitory effect of IL-4 on cytokine (IL-1 and TNF $\alpha$ ) production by the macrophage.

\section{Methods}

Reagents. Recombinant human IL-4 $\left(1 \times 10^{6} \mathrm{U} / \mathrm{mg}\right)$ and human IL-6 $\left(3.3 \times 10^{7} \mathrm{U} / \mathrm{mg}\right)$ were kindly provided by Sandoz Ltd. (Basel, Switzerland). Recombinant human IFN-gamma $\left(1.3 \times 10^{6} \mathrm{U} / \mathrm{mg}\right)$, IL-2 $\left(3.6 \times 10^{6} \mathrm{U} / \mathrm{mg}\right), \mathrm{TNF} \alpha\left(5 \times 10^{6} \mathrm{U} / \mathrm{mg}\right)$, and GM-CSF $\left(3.4 \times 10^{6}\right.$ $\mathrm{U} / \mathrm{mg}$ ) were obtained from Biogen S.A. (Geneva, Switzerland). Specific monoclonal antiserum to human IL-4 was procured from DNAX Inc. (Palo Alto, CA). Killed Staphylococcus aureus (k. S.aureus) was obtained from a single cultured colony and incubated overnight at $37^{\circ} \mathrm{C}$ in Mueller-Hinton medium (28). The bacteria were washed twice with PBS, resuspended in PBS containing $10 \% \mathrm{NaCl}$, placed at $85^{\circ} \mathrm{C}$ for $1 \mathrm{~h}$, washed again twice, and then resuspended in PBS. k. S.aureus processed in this manner were generously provided by Dr. S. Kantengwa, Allergy Unit, Geneva, Switzerland. BSA, lipopolysaccharide from $E$. coli (LPS), phenylmethylsufonyl fluoride, EDTA, Triton X-100 and protein-A Sepharose were obtained from Sigma Chemical Co. (St. Louis, MO). RPMI 1640, PBS, FCS, penicillin, streptomycin, and L-glutamine were purchased from GIBCO BRL (Paisley, Scotland).

Cell culture. Human alveolar macrophages were harvested from the uninvolved lung tissue of cigarette-smoking individuals undergoing surgical resection for pulmonary carcinoma (29). Segments or lobes were lavaged at room temperature with $250-500 \mathrm{ml}$ of sterile $0.9 \%$ $\mathrm{NaCl}$ using a 50-cc syringe introduced in the major bronchial airways and the cells obtained were $>90 \%$ macrophages as determined by differential counting of Wright-stained cytocentrifuge preparations. The remaining cells were primarily lymphocytes. The lavaged cells were centrifuged, washed once with PBS, and then resuspended in RPMI 1640 supplemented with $5 \%$ heat-inactivated FCS, and plated in 24well cluster plates (Costar Corp., Cambridge, MA) at a concentration of $1 \times 10^{6} \mathrm{cells} / \mathrm{ml}$. The cells were incubated for $1 \mathrm{~h}$ at $37^{\circ} \mathrm{C}$ to allow macrophage attachment. The wells were then washed three times with PBS to remove any floating cells (usually $<5 \%$ of cells). The adherent macrophages were cultured in the presence of new RPMI 1640 medium containing $5 \% \mathrm{FCS}$, penicillin $(100 \mathrm{U} / \mathrm{ml})$, streptomycin $(100$ $\mu \mathrm{g} / \mathrm{ml}$ ), and $2 \mathrm{mM} \mathrm{L}$-glutamine. The cells were maintained in humidified $95 \%$ air: $5 \% \mathrm{CO}_{2}$ for $72 \mathrm{~h}$.

Peripheral blood monocytes were obtained by phlebotomy of normal adult volunteers. The mononuclear fraction was purified by FicollHypaque gradient sedimentation (Pharmacia Fine Chemicals, Div. of
Pharmacia Inc., Piscataway, NJ). The monocytes were isolated by adherence to plastic at $37^{\circ} \mathrm{C}$ for $1 \mathrm{~h}$ followed by washing the plates three times with PBS to remove lymphocytes and nonadherent cells. The resulting adherent cells were $>95 \%$ monocytes. After overnight incubation, the spontaneously released monocytes were harvested and plated as above at a concentration of $1 \times 10^{6}$ cells $/ \mathrm{ml}$.

Collection of conditioned media. Macrophages were placed into culture as described above. Cells were treated with medium alone, k.S.aureus, and/or various concentrations of the different cytokines. After $72 \mathrm{~h}$ of incubation at $37^{\circ} \mathrm{C}$, the conditioned media were collected and stored at $-20^{\circ} \mathrm{C}$ until further analysis.

Immunological assays. Samples of conditioned medium were subjected to ELISAs for interstitial collagenase (30), 92-kD type IV collagenase (31), and TIMP (32). Our assays for interstitial collagenase and TIMP have been used extensively and employ specific polyclonal antisera that recognize either free collagenase or TIMP or the species complexed to one another with equal avidity $(30,32)$. The ELISA for 92-kD type IV collagenase is based upon minor modifications of an assay described recently (31). It also uses a rabbit anti-human polyclonal antibody that we have developed after immunization with enzyme purified from U937 cells (12) and is sensitive in the nanogram range. This antibody recognizes $92-\mathrm{kD}$ zymogen with equal facility to activated enzyme and does so whether or not TIMP is associated. There is no cross-reactivity by ELISA or Western analysis with any of the other known metalloproteinases, including the highly related 72-kD type IV collagenase. FCS contributes no immunologically cross-reactive material.

Metabolic labeling and immunoprecipitation studies. All samples subjected to immunoprecipitation were conditioned in the presence of ${ }^{35} \mathrm{~S}$-methionine for $24 \mathrm{~h}$. To determine the effects of IL-4, the cells were exposed to this agent for $24 \mathrm{~h}$ before labeling and then again during the study period. To begin the study period, culture medium was replaced with otherwise identical (except for the use of dialyzed 5\% FCS) methionine-free medium containing $50 \mu \mathrm{Ci} / \mathrm{ml}$ of ${ }^{35} \mathrm{~S}$-methionine (Amersham Corp., Zurich, Switzerland) and the cells were metabolically labeled for the next $24 \mathrm{~h}$. After collection, the samples of conditioned medium containing the labeled proteins were stored at $-70^{\circ} \mathrm{C}$ until further analysis.

For immunoprecipitation, polyclonal antisera to human interstitial collagenase, 92-kD type IV collagenase, and TIMP were used as reported previously $(2,5)$. Processed samples were applied to $12 \%$ polyacrylamide slab gels and electrophoresis was performed as described by King and Laemmli (33). The gels were exposed to Kodak XAR-5 $\mathrm{X}$-Omat film (Eastman Kodak Co., Rochester, NY) at $-70^{\circ} \mathrm{C}$.

IL-1 enzyme immunoassay. IL- $1 \alpha$ and IL- $1 \beta$ were measured by enzyme immunoassay using tandem mAbs as previously described (34).

$T N F \alpha$ radioimmunoassay. Radioimmunoassay for TNF $\alpha$ (IREMedgenix, Fleurus, Belgium) was performed according to the instructions of the suppliers.

$R N A$ preparation. Total cellular RNA from $15 \times 10^{6}$ stimulated and control human alveolar macrophages was extracted by the guanidine isothiocyanate method and purified by cesium chloride density gradient centrifugation as described previously $(35,36)$.

$R N A$ analysis. Total RNA ( $10 \mu \mathrm{g})$ was denatured with formaldehyde and 3-(4-morpholino) propane sulfonic acid (MOPS), electrophoresed on $1.2 \%$ agarose gels and stained for RNA integrity with ethidium bromide $(0.5 \mu \mathrm{g} / \mathrm{ml})$. After transfer to a Biodyne nylon membrane (Pall ${ }^{\mathrm{TM}}$ Ultrafine Filtration Corp., Glen Cove, NY), filters were baked for $2 \mathrm{~h}$ at $80^{\circ} \mathrm{C}$ before prehybridization for $6 \mathrm{~h}$ at $58^{\circ} \mathrm{C}$ with a mixture containing 50\% deionized formamide, 5\% 50× Denhardt's solution, $0.25 \mathrm{M}$ Pipes, $5 \mathrm{M} \mathrm{NaCl}, 0.5 \mathrm{M}$ EDTA, $10 \% \mathrm{SDS}$, and 250 $\mu \mathrm{g} / \mathrm{ml}$ salmon sperm DNA. Hybridization was performed at $58^{\circ} \mathrm{C}$ overnight with a $92-\mathrm{kD}$ type IV collagenase $\mathrm{CDNA}$ probe (provided by Dr. Gregory Goldberg, Washington University School of Medicine, St. Louis, MO) (12) labeled with $\alpha-\left[{ }^{32} \mathrm{P}\right] \mathrm{dUTP}$ of specific activity 250 $\mu \mathrm{Ci}$. The $92-\mathrm{kD}$ type IV collagenase cDNA is a $1.55-\mathrm{kb}$ clone inserted in XbaI site of Bluescript KS (Stratagene Inc., La Jolla, CA). The probe 
was linearized by BamHI and transcribed with bacteriophage T7. The filters were then washed to a stringency of $0.1 \%$ standard saline citrate (SSC), $0.1 \%$ SDS at $75^{\circ} \mathrm{C}$. The filters were exposed to Kodak XAR $\mathrm{X}$-Omat film (Eastman Kodak Co.) for $24-48 \mathrm{~h}$ at $-70^{\circ} \mathrm{C}$.

\section{Results}

To determine which cytokines released by activated T lymphocytes are capable of regulating macrophage metalloproteinase or TIMP expression, freshly harvested human alveolar macrophages were placed in culture in the presence of IL-2, IL-4, IL-6, IFN-gamma, TNF $\alpha$, or GM-CSF. After $72 \mathrm{~h}$ of incubation, conditioned media were harvested and subjected simultaneously to ELISAs for interstitial collagenase, 92-kD type IV collagenase, and TIMP. Interstitial collagenase was not secreted by basal macrophages and no tested cytokine induced its release. As shown in Table I, 92-kD type IV collagenase and TIMP were constitutively produced by the adherent alveolar macrophages at 380 and $103 \mathrm{ng} / 10^{6}$ cells, respectively. Interestingly, the addition of IL-4 $(2 \mathrm{ng} / \mathrm{ml})$ to culture medium reduced secretion of $92-\mathrm{kD}$ enzyme by $>50 \%$. The presence of IL-6 resulted in a twofold increase in TIMP production along with significant, but inconstant effect upon metalloproteinase levels. These results for IL-6 confirm and extend the observations of Lotz and Guerne (37), who reported specific stimulation of TIMP production by this cytokine in human fibroblasts. Finally, IFN-gamma suppressed $92-k D$ enzyme release, consistent with our own previous observations (5). None of the other agents induced changes in metalloproteinase or TIMP biosynthesis that could not be explained by parallel alterations in levels of total new protein synthesis.

To further characterize IL-4 effects upon metalloproteinase production, a dose titration experiment was performed. $\mathrm{Hu}$ man alveolar macrophages were exposed to various concentrations of IL-4 for $72 \mathrm{~h}$ and secretion of $92-\mathrm{kD}$ type IV collagenase and TIMP were quantified by ELISA on the same samples of conditioned medium. As shown in Fig. 1, spontaneous re-

Table I. Effect of Various Cytokines on Metalloproteinase Production by Human Alveolar Macrophages

\begin{tabular}{lcc}
\hline \multicolumn{1}{c}{ Incubation condition } & $92 \mathrm{kD}$ & TIMP \\
\hline \multicolumn{1}{c}{$72 h$} & \% of control & \% of control \\
Medium alone & 100 & 100 \\
Il-2 $(1 \mathrm{ng} / \mathrm{ml})$ & $106 \pm 6$ & $111 \pm 17$ \\
IL-4 $(2 \mathrm{ng} / \mathrm{ml})$ & $\underline{46} \pm 8^{*}$ & $97 \pm 4$ \\
IL-6 $(2 \mathrm{ng} / \mathrm{ml})$ & $136 \pm 13$ & $\underline{180} \pm 17^{*}$ \\
IFN-gamma $(500 \mathrm{U} / \mathrm{ml})$ & $\underline{49} \pm 15^{*}$ & $128 \pm 20$ \\
TNF $\alpha(1 \mathrm{ng} / \mathrm{ml})$ & $116 \pm 15$ & $120 \pm 6$ \\
GM-CSF $(10 \mathrm{ng} / \mathrm{ml})$ & $138 \pm 38$ & $151 \pm 8$
\end{tabular}

Human alveolar macrophages were incubated in the presence of each of the various cytokines for $72 \mathrm{~h}$. Conditioned media were analyzed for secreted 92-kD type IV collagenase and TIMP by ELISA. No interstitial collagenase was detected under any of the conditions tested. Data are expressed as a percentage of basal production levels \pm SEM ( $n=5$ separate experiments). Amounts of spontaneously secreted 92-kD type IV collagenase and TIMP were ${ }^{a} 380 \mathrm{ng} / \mathrm{ml}$ and ${ }^{b} 103$ $\mathrm{ng} / \mathrm{ml}$, respectively. ${ }^{*} P<0.005$, as compared with control by Kruskal-Wallis.

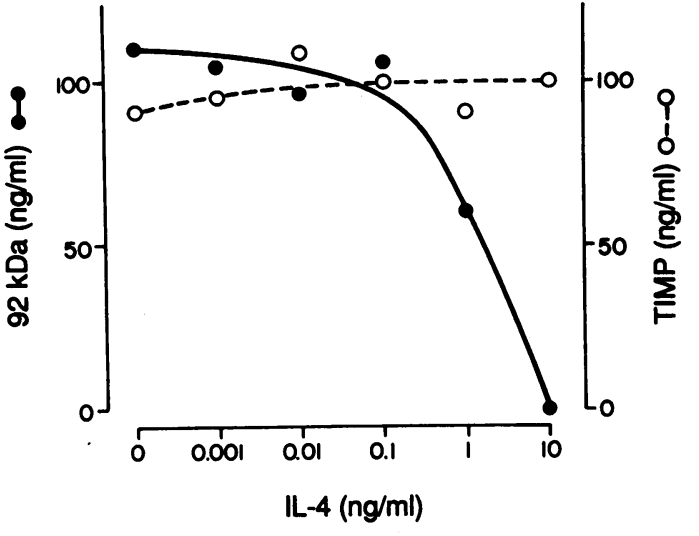

Figure 1. IL-4 induces a dose-dependent suppression of 92-kD type IV collagenase without affecting TIMP release. Human alveolar macrophages were cultured $\left(\sim 1 \times 10^{6}\right.$ cells $\left./ \mathrm{ml}\right)$ in the presence of increasing concentrations of IL-4. After $72 \mathrm{~h}$ of incubation, conditioned media were harvested and each sample was assayed for $92-\mathrm{kD}$ type IV collagenase and TIMP by ELISA.

lease of $92-\mathrm{kD}$ enzyme was inhibited $\sim 50 \%$ by $1 \mathrm{ng} / \mathrm{ml}$ of IL-4 whereas nearly complete inhibition was achieved at 10 $\mathrm{ng} / \mathrm{ml}$. Although such a dose response was typical, both greater and lesser degrees of sensitivity to IL-4 were observed with different individuals' alveolar macrophages (Table II, Figs. 2 and 3 ). In contrast, TIMP production was unaffected by any concentration of IL- 4 tested. To ensure that changes observed in metalloproteinase production were the consequence of IL-4 activity alone, specific antiserum to this cytokine was used to abrogate its effects. As shown in Table II, $10 \mathrm{ng} / \mathrm{ml}$ of IL-4 reduced spontaneous production of $92-\mathrm{kD}$ type IV collagenase by $\sim 60 \%$, an effect completely reversed by the presence of IL-4-specific antiserum. The antiserum alone caused no change in $92-\mathrm{kD}$ enzyme secretion.

Although human macrophages in culture fail to elaborate interstitial collagenase spontaneously, production of this enzyme can be induced by exposing the cells to activating agents such as LPS or phagocytizable material. As shown in Table III, collagenase secretion was stimulated to readily measureable levels by the addition of k.S.aureus to cell cultures ( 10 bacteria / cell). Similarly, production of 92-kD enzyme and of TIMP were increased substantially from basal levels. IL-4 ( $10 \mathrm{ng} / \mathrm{ml})$ reduced spontaneous production of $92-\mathrm{kD}$ enzyme by $\sim 50 \%$.

Table II. Effect of Anti-IL-4 Antibody on IL-4-treated Human Alveolar Macrophages

\begin{tabular}{lcc}
\hline \multicolumn{1}{c}{ Incubation condition } & $92 \mathrm{kD}$ & TIMP \\
\hline \multicolumn{1}{c}{$72 h$} & \multicolumn{3}{c}{$\mathrm{ng} / \mathrm{ml}$} \\
Medium alone & 407 & 115 \\
IL-4 $(10 \mathrm{ng} / \mathrm{ml})$ & 172 & 100 \\
Anti-IL-4 Ab $(10 \mu \mathrm{g} / \mathrm{ml})$ & 433 & 117 \\
IL-4 + anti-IL-4 Ab & 413 & 122 \\
& &
\end{tabular}

Human alveolar macrophages were cultured in the presence of $\mathrm{IL}-4$, antibody to IL-4, or both agents in combination for $72 \mathrm{~h}$. Supernatants were analyzed for secreted levels of 92-kD type IV collagenase and TIMP. These results were confirmed by two separate experiments. 


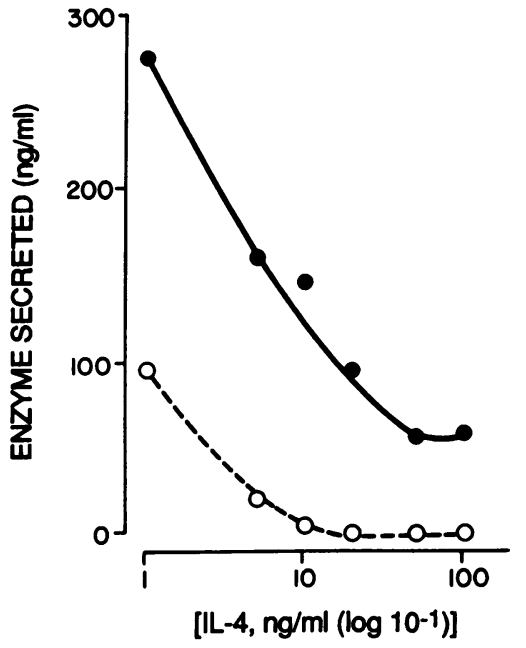

After stimulation with killed bacteria, interstitial collagenase secretion was decreased $90 \%$ by IL-4, whereas $92-\mathrm{kD}$ enzyme release was inhibited $>50 \%$. Thus, IL-4 is capable of reducing both basal and stimulated metalloproteinase production with nearly equal efficacy. Upon simultaneous analysis of conditioned media samples, TIMP biosynthesis was unaffected by IL-4.

A dose titration was also performed to further characterize IL-4 inhibition of stimulated macrophage metalloproteinase production (Fig. 2). Increasing concentrations of IL-4 were added to k.S. aureus-stimulated macrophages and the conditioned media simultaneously assayed for interstitial collagenase and 92-kD type IV collagenase. As shown in Fig. 2, suppression of each metalloenzyme by IL-4 was parallel and very
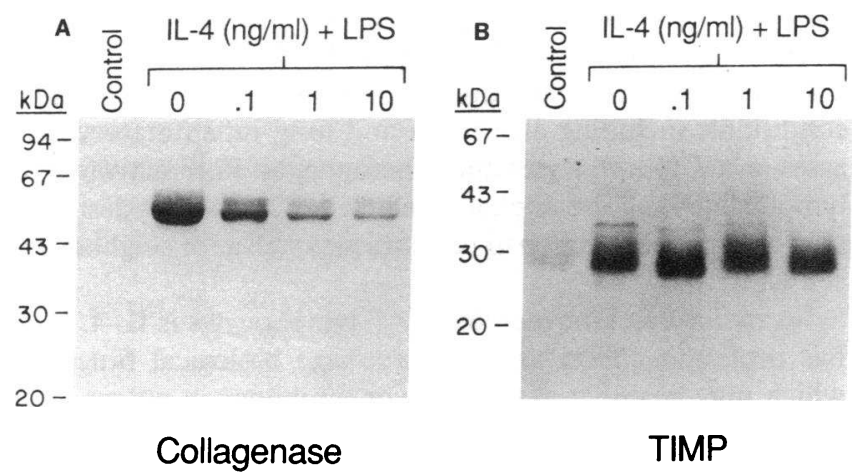

Figure 3. IL-4 inhibition of metalloproteinase production is mediated at the level of enzyme biosynthesis. Human alveolar macrophages were stimulated with LPS $(2.5 \mu \mathrm{g} / \mathrm{ml})$ and cultured in the presence of increasing concentrations of IL-4. Cells were metabolically labeled with ${ }^{35} \mathrm{~S}$-methionine as described in Methods and conditioned media immunoprecipitated with specific antisera. $(A)$ Labeled conditioned media proteins were immunoprecipitated with antiserum to interstitial collagenase. $(B)$ The same labeled conditioned media proteins were immunoprecipitated with antiserum to TIMP. Note the stimulation in the biosynthesis of both proteins by LPS as compared with control cells. Also note the marked IL-4-induced suppression of interstitial collagenase biosynthesis without effect upon TIMP production.

Table III. Effect of IL-4 on Unstimulated and Stimulated Human Alveolar Macrophages

\begin{tabular}{lrrr}
\hline \multicolumn{1}{c}{ Incubation condition } & \multicolumn{1}{c}{ Interstitial collagenase } & $92 \mathrm{kD}$ & TIMP \\
\hline \multicolumn{1}{c}{$72 h$} & \multicolumn{3}{c}{$n g / \mathrm{ml}$} \\
Medium alone & $<10$ & 384 & 68 \\
IL-4 $(10 \mathrm{ng} / \mathrm{ml})$ & $<10$ & 183 & 82 \\
k. $S$. aureus $(10$ bacteria $/ \mathrm{m} 0)$ & 109 & 944 & 338 \\
IL-4 + k. S. aureus & 10 & 456 & 272 \\
& & &
\end{tabular}

Human alveolar macrophages were exposed to IL-4, k. S. aureus, or both agents in combination for $72 \mathrm{~h}$. Conditioned media were analyzed for content of interstitial collagenase, 92-kD type IV collagenase, and TIMP. These results were confirmed by three separate experiments.

nearly identical. $50 \%$ inhibition of the release of each proteinase was observed at $0.1-0.5 \mathrm{ng} / \mathrm{ml}$ of IL-4.

To gain insights into the intracellular processes responsible for IL-4 inhibition of metalloproteinase production, metabolic labeling and immunoprecipitation experiments were performed. Human alveolar macrophages were cultured in the presence of LPS to stimulate interstitial collagenase and TIMP biosynthesis. The LPS-stimulated cells were then exposed to ${ }^{35} \mathrm{~S}$-methionine in the presence or absence of IL-4 and the newly synthesized labeled proteins immunoprecipitated with specific antisera to interstitial collagenase and TIMP. As shown in Fig. 3, IL-4 reduced LPS-stimulated interstitial collagenase biosynthesis in a manner completely analogous to its effects upon steady state protein levels shown in Fig. 2. In contrast, LPS-stimulated biosynthesis of TIMP was entirely unaffected, even at the highest tested concentration of the cytokine. These data demonstrate that IL-4 exerts its action at the level of new protein synthesis. Furthermore, IL-4 is capable of inhibiting metalloproteinase biosynthesis even after macrophage stimulation by different ligands (soluble endotoxin or the ingestion of k.S.aureus).

To further assess mechanism of regulatory control exerted by IL-4, we examined steady state mRNA levels by Northern hybridization. Total RNA was isolated as described in Methods, resolved by formaldehyde-agarose electrophoresis, and hybridized to 92-kD type IV collagenase cDNA (12). As shown in Fig. 4, basal alveolar macrophages contained considerable amounts of $92-\mathrm{kD}$ mRNA. Upon exposure of the cells to IL-4

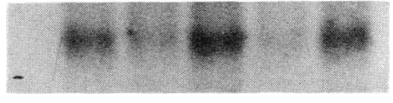

$92 \mathrm{kD}$

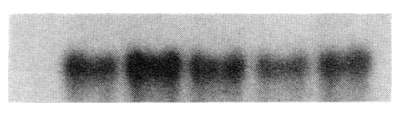

Actin

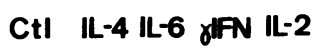

Figure 4. Pretranslational inhibition of metalloproteinase expression by IL-4. Human alveolar macrophages were cultured for $48 \mathrm{~h}$ with medium alone, IL$4(10 \mathrm{ng} / \mathrm{ml})$, IL-6 (2 $\mathrm{ng} / \mathrm{ml})$, IFN-gamma $(500 \mathrm{U} / \mathrm{ml})$, or IL-2 (1 $\mathrm{ng} / \mathrm{ml}$ ). Total RNA was harvested and subjected to Northern analysis using a cDNA probe for $92-\mathrm{kD}$ type IV collagenase (12). Note pretranslational inhibition of constitutive $92-\mathrm{kD}$ enzyme production by IL-4 and IFN-gamma. The stimulatory effect of IL-6 upon steady state 92-kD mRNA levels was not consistently observed. 
(10 $\mathrm{ng} / \mathrm{ml})$ or IFN- $\gamma(500 \mathrm{U} / \mathrm{ml}), 92-\mathrm{kD}$-specific message was decreased drastically. Therefore, IL-4 inhibits metalloproteinase expression in a pretranslational manner.

IFN-gamma, another cytokine released by activated T lymphocytes, has been shown to directly antagonize many of the biological activities of IL-4 $(26,27)$. To evaluate the effects of the simultaneous presence of both cytokines upon macrophage metalloproteinase production, cells were incubated with IL-4 in the presence of increasing concentrations of IFN- $\gamma$. As shown in Fig. $5 A$, IFN- $\gamma$ suppressed production of $92-\mathrm{kD}$ collagenase, consistent with its previously reported capacity to inhibit metalloproteinase secretion (5). IL-4 alone also decreased $92-\mathrm{kD}$ enzyme synthesis as discussed above. When both cytokines were present together, production of the $92-\mathrm{kD}$ enzyme was inhibited by $>75 \%$, an amount much larger than each agent caused alone in this experiment. Despite such cooperativity, we failed to detect synergism between IFN- $\gamma$ and IL4. Low concentrations of either agent were not potentiated by the simultaneous presence of small amounts of the other (not shown).

Since production of cytokines is highly relevant to the inflammatory response, we determined amounts of IL- $1 \alpha$ and TNF $\alpha$ secreted by the same cultures of macrophages that had been treated with IL-4 in the presence of increasing amounts of IFN-gamma as described above. Consistent with previous reports $(23,24)$, IL-4 caused suppression of macrophage release of IL- $1 \alpha$ and TNF $\alpha$, whereas IFN- $\gamma$ potently stimulated secretion of these cytokines (Figs. 5, $B$ and $C$ ). As also shown in Fig. 5 , IL-4 clearly antagonized the cytokine stimulation induced by IFN- $\gamma$. These data indicate that IL -4 and IFN- $\gamma$ oppose each other's actions in modulating macrophage cytokine production, whereas they function coordinately to suppress the biosynthesis of metalloproteinases. Therefore, although secreted proteinases and cytokines (via their actions on fibroblasts [3, 4]) represent important components of the macrophage's arsenal to direct matrix degradation, their expression appears to be regulated quite differently.

To gain insights into the role of cell differentiation upon the capacity of IL-4 to suppress mononuclear phagocyte metalloproteinase production, we examined the effects of this cytokine upon 92-kD enzyme release by freshly harvested human blood monocytes. As shown in Table IV, IL-4 caused a dose-dependent and significant reduction in the spontaneous secretion of
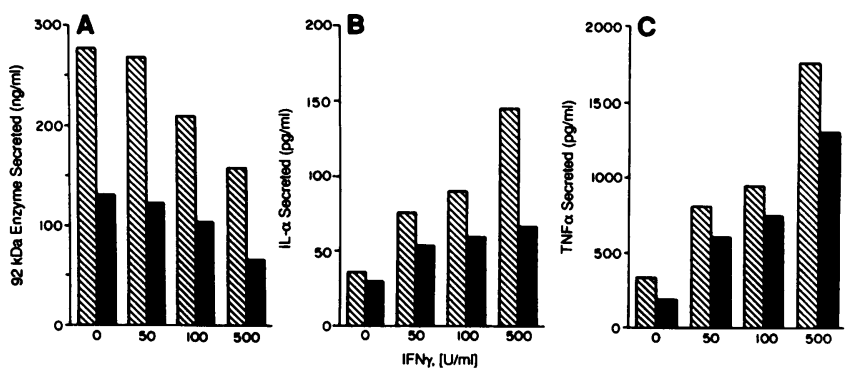

Figure 5. Effect of IL-4 and IFN-gamma on macrophage secretion of 92-kD type IV collagenase, IL-1 $\alpha$, and TNF $\alpha$. Human alveolar macrophages $\left(\sim 1 \times 10^{6} / \mathrm{ml}\right)$ were cultured for $72 \mathrm{~h}$ with increasing concentrations of IFN-gamma in the presence or absence of IL-4 (10 $\mathrm{ng} / \mathrm{ml}$ ). ( $A$ ) 92-kD type IV collagenase, $(B)$ IL-1 $\alpha$, and (C) TNF $\alpha$ secreted into culture medium were quantified as described under Methods. $\mathbb{Q}, \mathrm{IL}-4: 0 ; \mathbb{N}, \mathrm{IL}-4: 10 \mathrm{ng} / \mathrm{ml}$.
Table IV. Effect of IL-4 on Blood Monocyte Production of 92-kD Type IV Collagenase and TIMP

\begin{tabular}{|c|c|c|}
\hline Incubation condition & $92 \mathrm{kD}$ & TIMP \\
\hline $48 h$ & \multicolumn{2}{|c|}{$\%$ of control } \\
\hline Monocytes & 100 & 100 \\
\hline Monocytes + IL-4 (1 ng/ml) & $79 \pm 8$ & $146 \pm 9$ \\
\hline Monocytes + IL-4 $(10 \mathrm{ng} / \mathrm{ml})$ & $48 \pm 14$ & $128 \pm 3$ \\
\hline Monocytes + k. S. aureus ( 10 bacteria/MØ) & 100 & 100 \\
\hline Monocytes + k. S. aureus + IL-4 $(10 \mathrm{ng} / \mathrm{ml})$ & $34 \pm 17$ & $94 \pm 24$ \\
\hline
\end{tabular}

* Human monocytes were isolated and placed in culture for $48 \mathrm{~h}$ as described under Methods. Secreted 92-kD type IV collagenase and TIMP were quantified by ELISA. Results shown are the mean values from three separate experiments \pm standard deviation. Controls are defined as equal to $100 \%$ and include monocytes incubated in culture medium alone and monocytes cultured in the presence of killed $S$. aureus. Effects of IL-4 are compared with the appropriate control. Amounts of spontaneously secreted $92-\mathrm{kD}$ type IV collagenase and TIMP were $\sim 1.0$ and $0.7 \mu \mathrm{g} / \mathrm{ml}$, respectively.

92-kD enzyme by monocytes, very similar to its action on alveolar macrophages (Table I, Fig. 1). It should be noted, however, that such responsiveness stands in direct contrast to the lack of efficacy of LPS, phorbol esters, and phagocytized material on monocyte metalloenzyme production; when exposed to these latter agents, the immature cells are incapable of altering their proteinase or TIMP expression in a manner displayed by the more mature tissue macrophage $(2,8)$.

\section{Discussion}

The inflammatory response is characterized by a cascade of events that often leads to tissue destruction and remodeling. Released chemotactic factors trigger an influx of inflammatory cells capable of secreting cytokines and cytokine inhibitors. These factors may amplify or constrain the reactive process. Two prominent cell types present in a variety of inflammatory conditions, including arthritides and lung inflammatory diseases, are $\mathrm{T}$ lymphocytes and macrophages. Both activated $\mathrm{T}$ lymphocytes and macrophages release soluble factors designed to modulate the function of each other as well as of neighboring cell types.

A major cytokine secreted by T lymphocytes is IL-4. IL-4 has profound effects upon macrophage biological function, which may be either stimulatory or inhibitory in nature. The cytokine enhances MHC class II antigen and CR 3 and Fc $\epsilon$ RIIb expression and promotes mononuclear phagocyte cellular differentiation (22). However, IL-4 also decreases Fc $\gamma$ RI-II-III expression, inhibits the monocyte's production of IL-1, TNF $\alpha$, and IL-6 $(23,24)$, and most recently has been shown to block osteoclast formation from progenitor mononuclear cells (25). The data presented in this manuscript demonstrate that IL-4 can potently suppress the macrophage's capacity to produce its two principal metalloproteinases, $92-\mathrm{kD}$ type IV collagenase and interstitial collagenase, without affecting the simultaneous release of the counter-regulatory inhibitor TIMP. Metalloproteinase biosynthesis was blocked by IL- 4 both constitutively and also in cells stimulated by the ingestion of $\mathrm{k}$. S.aureus or by exposure to endotoxin. Although our specific antisera and 
cDNA probes do not distinguish between activated and zymogen enzyme forms, it is very likely that diminished metalloproteinase activity also results from IL-4 exposure. The inability of IL-4 to modulate TIMP levels provides yet another example, along with retinoids (36), IFN- $\gamma(5)$, and IL-6 (37), of the potential for dissociated regulation of secreted metalloproteinases versus TIMP.

We have previously reported (5) that IFN-gamma, another cytokine released by activated $\mathrm{T}$ lymphocytes that is capable of influencing macrophage function, inhibits the latter cells' capacity for metalloproteinase production. Interstitial collagenase and stromelysin biosynthesis were exquisitely sensitive to this agent ( $10 \mathrm{U} / \mathrm{ml}$ caused $50 \%$ inhibition; [5]), whereas 92 $\mathrm{kD}$ enzyme production was affected at higher cytokine concentrations $(>50 \mathrm{U} / \mathrm{ml})$. This result was quite unexpected since IFN- $\gamma$ is a potent upregulator of virtually all other macrophage biological functions, including stimulation of class II MHC antigen and $F c \gamma R$ expression, antigen presenting capacity, ADCC activity, antibody-dependent cellular cytotoxicity, tumoricidal and microbicidal activity, oxidative metabolism, and the production of monokines $(6,7,26,27)$. Interestingly, for all of these activities except class II MHC antigen expression and antigen-presenting capacity, IL-4 specifically antagonizes the action of IFN-gamma $(26,27)$. In this regard, our findings of IL-4 potentiation of IFN- $\gamma$ 's ability to inhibit macrophage metalloproteinase production may be of considerable biological importance. Although the actions of both lymphokines appear to be additive rather than synergistic, it is clear that potent suppression of enzyme biosynthesis results from their combined presence (Fig. 5).

Another cytokine secreted by T lymphocytes, IL-6, has been reported to specifically stimulate TIMP production in fibroblasts without measureable effect upon metalloproteinases (37). The data in the present study examining a different cell type, the human alveolar macrophage, confirm these actions. IL-6 stimulated TIMP biosynthesis by twofold; production of interstitial collagenase and 92-kD type IV collagenase were only inconsistently affected (Table I). In fact, when IL-6 and IL-4 were present simultaneously in culture medium, each cytokine appeared to function independently of the other; IL-6 specifically augmented TIMP production whereas IL-4 blocked the release of metalloproteinases (data not shown).

Mononuclear phagocytes have the capacity to mediate matrix degradation by two distinct biological strategies, the elaboration of cytokines such as IL-1 and TNF $\alpha$, which stimulate fibroblast production of metalloproteinases, and also by secretion of their own battery of enzymes. The data presented here strongly suggest that control mechanisms for each of these pathways are separate and dissociated. IL-4 suppresses macrophage secretion of IL- $1 \beta$, IL-1 $\alpha$, and $\operatorname{TNF} \alpha(23,24)$, results which we have confirmed in this study. Similarly, this lymphokine inhibits the macrophage's own expression of matrix metalloproteinases. However, IFN- $\gamma$ potently enhances macrophage production of the above cytokines $(6,7)$ while ablating the cells' capacity for degradative enzyme release (5). Indeed, we have shown that although IL- 4 antagonizes IFN- $\gamma-$ mediated stimulation of macrophage cytokine production, it potentiates the latter's suppression of macrophage metalloproteinases (Fig. 5). In this regard, it is of interest that emerging data suggest the existence of different subpopulations of $T$ lymphocytes that preferentially express either IFN- $\gamma$ or IL-4 (38). Such cell subsets could conceivably modulate monocyte-mac- rophage production of metalloproteinases and cytokines differentially. In any event, although macrophages can exert control over matrix degradation via directing the production of fibroblast-stimulating cytokines and also by the elaboration of their own metalloproteinases, cellular mechanisms controlling these pathways appear to be different.

The data presented in this report strongly suggest that soluble factors released by activated T lymphocytes function coordinately to suppress the macrophage's capacity to synthesize metalloproteinases and thereby to promote extracellular matrix degradation. IL-4 and IFN-gamma block the biosynthesis of interstitial collagenase and 92-kD type IV collagenase without altering TIMP production. IL-6 stimulates the synthesis of TIMP in the absence of consistent effect upon the metalloproteinases. Other $T$ cell cytokines appear to lack significant capacity to modulate macrophage expression of enzymes or inhibitors. In this regard, it is interesting that we have recently described the marked induction of mononuclear phagocyte cytokine (IL-1, TNF $\alpha$ ) release by a mechanism involving cell surface contact between activated $T$ lymphocytes and monocytes (Vey, E., J.-H. Zhang, and J.-M. Dayer, manuscript submitted for publication). If such cell-cell contact were to also stimulate metalloproteinase expression, a biological strategy might exist whereby $\mathrm{T}$ cells suppress macrophage degradative capacity by the release of soluble factors and enhance it via direct cell surface interaction. Studies to address this possibility are currently in progress.

\section{Acknowledgments}

We thank Marie-Therese Kaufmann and Fadia El Habre for technical assistance and Lou Anne Davidson for secretarial assistance in the preparation of this manuscript. We also thank Dr. Gregory Goldberg (Washington University School of Medicine, St. Louis, MO) for supplying the cDNA probe to $92-\mathrm{kD}$ type IV collagenase.

This work was supported by grants from the Swiss National Science Foundation (FNRS 32-26426-89) and the Zyma Foundation. Support was also provided from United States Public Health Service Grants AR35805, HL29594, and AR32087. Sylvie Lacraz is the recipient of an M.D./Ph.D. fellowship at the Medical Faculty of Geneva University, donated by the Foundation "Centre de recherches medicales C. et E. de Reuter and by the Swiss Academy of Medical Sciences.

\section{References}

1. Welgus, H. G., E. J. Campbell, Z. Bar-Shavit, R. M. Senior, and S. L. Teitelbaum. 1985. Human alveolar macrophages produce a fibroblast-like collagenase and collagenase inhibitor. J. Clin. Invest. 76:219-224.

2. Welgus, H. G., E. J. Campbell, J. D. Cury, A. Z. Eisen, R. M. Senior, S. M. Wilhelm, and G. I. Goldberg. 1990. Neutral metalloproteinases produced by human mononuclear phagocytes. Enzyme profile, regulation, and expression during cellular development. J. Clin. Invest. 86:1496-1502.

3. Dayer, J.-M., B. de Rochemonteix, B. Burrus, S. Demczuk, and C. A. Dinarello. 1986. Human recombinant interleukin-1 stimulates collagenase and prostaglandin $\mathrm{E}_{2}$ production by human synovial cells. J. Clin. Invest. 77:645648.

4. Dayer, J.-M., A. Beutler, and A. Cerami. 1985. Cachectin/tumor necrosis factor stimulates collagenase and prostaglandin $\mathrm{E}_{2}$ production by human synovial cells and dermal fibroblasts. J. Exp. Med. 162:2163-2168.

5. Shapiro, S. D., E. J. Campbell, D. K. Kobayashi, and H. G. Welgus. 1990 Immune modulation of metalloproteinase production in human macrophages. Selective pre-translational suppression of interstitial collagenase and stromelysin biosynthesis by gamma interferon. J. Clin. Invest. 86:1204-1210.

6. Gonwa, T. A., J. P. Frost, and R. W. Karr. 1986. All human monocytes have the capability of expressing HLA-DQ and HLA-DR molecules upon stimulation with interferon-gamma. J. Immunol. 137:519-524.

7. Mentzer, S. J., D. V. Faller, and S. J. Burakoff. 1986. Interferon-gamma 
induction of LFA-1-mediated homotypic adhesion of human monocytes. J. Immunol. 137:108-113.

8. Campbell, E. J., J. D. Cury, S. D. Shapiro, G. I. Goldberg, and H. G. Welgus. 1991. Neutral proteinases of human mononuclear phagocytes: cellular differentiation markedly alters cell phenotype for serine proteinases, metalloproteinases, and TIMP. J. Immunol. 146:1286-1293.

9. Shapiro, S. D., E. J. Campbell, D. K. Kobayashi, and H. G. Welgus. 1991. Dexamethasone selectively modulates basal and lipopolysaccharide-induced metalloproteinase and tissue inhibitor of metalloproteinase production by human alveolar macrophages. J. Immunol. 146:2724-2729.

10. Welgus, H. G., N. L. Connolly, and R. M. Senior. 1986. TPA-differentiated U937 cells express a macrophage-like profile of neutral proteinases. High levels of secreted collagenase and collagenase inhibitor accompany low levels of intracellular elastase and cathepsin G. J. Clin. Invest. 77:1675-1681.

11. Hibbs, M. S., J. R. Hoidal, and A. H. Kang. 1987. Expression of a metalloproteinase that degrades native type $\mathrm{V}$ collagen and denatured collagens by cultured human alveolar macrophages. J. Clin. Invest. 80:1644-1650.

12. Wilhelm, S. M., I. E. Collier, B. L. Marmer, A. Z. Eisen, G. A. Grant, and G. I. Goldberg. 1989. SV 40-transformed human lung fibroblasts secrete a 92$\mathrm{kDa}$ type IV collagenase which is identical to that secreted by normal human macrophages. J. Biol. Chem. 264:17 213-17 221.

13. Murphy, G., M. I. Cockett, R. V. Ward, and A. J. P. Docherty. 1991. Matrix metalloproteinase degradation of elastin, type IV collagen and proteoglycan: a quantitative comparison of the activities of $95 \mathrm{kDa}$ and $72 \mathrm{kDa}$ gelatinases, stromelysins- 1 and 2 and punctuated metalloproteinase (PUMP). Biochem. J. 277:277-279.

14. Senior, R. M., G. L. Griffin, C. J. Fliszar, S. D. Shapiro, G. I. Goldberg, and H. G. Welgus. 1991. Human 92- and 72-kilodalton type IV collagenases are elastases. J. Biol. Chem. 266:7870-7875.

15. Henney, A. M., P. R. Wakeley, M. J. Davies, K. Foster, R. Hembry, G. Murphy, and S. Humphries. 1991. Localization of stromelysin gene expression in atherosclerotic plaques by in situ hybridization. Proc. Natl. Acad. Sci. USA. 88:8154-8158.

16. McCachren, S. S. 1991. Expression of metalloproteinases and metalloproteinase inhibitor in human arthritic synovium. Arthritis Rheum. 34:1085-1093.

17. Howard, M., F. John, M. Hilfiker, B. Johnson, K. Takatsu, T. Kamaoka, and W. E. Paul. 1982. Identification of a T cell-derived B cell growth factor distinct from interleukin 2. J. Exp. Med. 155:914-923.

18. Coffman, R. L., J. Ohara, M. W. Bond, J. Carty, A. Zlotnik, and W. E. Paul. 1986. B cell stimulatory factor-1 enhances the IgE response of lipopolysaccharide-activated B cells. J. Immunol. 136:4538-4541.

19. Kurt-Jones, E. A., S. Hamberg, J. Ohara, W. E. Paul, and A. K. Abbas. 1987. Heterogeneity of helper/inducer T lymphocytes. I. Lymphokine production and lymphokine responsiveness. J. Exp. Med. 166:1774-1787.

20. Smith, C. A., and D. M. Rennick. 1986. Characterization of a murine lymphokine distinct from interleukin 2 and interleukin 3 (IL-3) possessing a T-cell growth factor activity and a mast-cell growth factor activity that synergizes with IL-3. Proc. Natl. Acad. Sci. USA. 83:1857-1861.

21. Rennick, D., G. Yang, S. C. Muller, C. Smith, N. Arai, Y. Takabe, and L. Gemmell. 1987. Interleukin 4 (B-cell stimulatory factor 1) can enhance or antagonize the factor-dependent growth of hemopoietic progenitor cells. Proc. Natl. Acad. Sci. USA. 84:6889-6893.

22. TeVelde, A. A., J. P. G. Klomp, B. A. Yard, J. E. deVries, and C. G.
Figdor. 1988. Modulation of phenotypic and functional properties of human peripheral blood monocytes by IL-4. J. Immunol. 140:1548-1554.

23. TeVelde, A. A., R. J. F. Huijbens, K. Heije, J. E. deVries, and C. G. Figdor. 1990. Interleukin-4 (IL-4) inhibits secretion of IL-1 $\beta$, tumor necrosis factor $\alpha$, and IL-6 by human monocytes. Blood. 76:1392-1397.

24. Hart, P. H., G. F. Vitti, D. R. Burgess, G. A. Whitty, D. S. Piccoli, and J. A. Hamilton. 1989. Potential antiinflammatory effects of interleukin 4: suppression of human monocyte tumor necrosis factor $\alpha$, interleukin 1, and prostaglandin $\mathrm{E}_{2}$. Proc. Natl. Acad. Sci. USA. 86:3803-3807.

25. Shioi, A., S. L. Teitelbaum, F. P. Ross, H. G. Welgus, J. Ohara, H. Suzuki, and D. L. Lacey. 1991. Interleukin-4 inhibits murine osteoclast formation in vitro. J. Cell. Biochem. 47:1-6.

26. Rousset, F., R. deWaal Malefijt, B. Slierendrecht, J. P. Aubry, J. Bonnefoy, T. DeFrance, J. Bancherau, and J. E. deVries. 1988. Regulation of Fc receptor for IgE (CD23) and class II MHC antigen expression of Burkitt's lymphoma cell lines by human IL-4 and IFN-gamma. J. Immunol. 140:2625-2632.

27. TeVelde, A. A., R. J. F. Huijbens, J. E. deVries, and C. G. Figdor. 1990. IL-4 decreases FcgammaR membrane expression and FcgammaR-mediated cytotoxic activity of human monocytes. J. Immunol. 144:3046-3051.

28. Bucker, E. R., and S. E. Martin. 1981. Superoxide dismutase activity in thermally stressed Staphylococcus aureus. Applied Environ. Microbiol. 41:449454.

29. Galve-de Rochemonteix, B., L. P. Nicod, A. F. Junod, and J.-M. Dayer. 1990. Characterization of a specific 20 - to $25-\mathrm{kD}$ interleukin-1 inhibitor from cultured human lung macrophages. Am. J. Respir. Cell Mol. Biol. 3:355-361.

30. Cooper, T. W., E. A. Bauer, and A. Z. Eisen. 1982. Enzyme-linked immunosorbant assay for human skin collagenase. Collagen Relat. Res. 3:205-216.

31. Bergmann, U., J. Michaelis, R. Oberhoff, V. Knauper, R. Beckmann, and H. Tschesche. 1989. Enzyme-linked immunosorbent assays for the quantitative determination of human leukocyte collagenase and gelatinase. J. Clin. Chem. Clin. Biochem. 27:351-359.

32. Welgus, H. G., and G. P. Stricklin. 1983. Human skin fibroblast collagenase inhibitor: comparative studies in human connective tissues, serum, and amniotic fluid. J. Biol. Chem. 258:12 259-12 264.

33. King, J., and U. K. Laemmli. 1971. Polypeptides of the tail fibres of bacteriophage T4. J. Mol. Biol. 62:465-477.

34. Grassi, J., Y. Frobert, P. Pradelles, F. Chercuite, D. Gruaz, J.-M. Dayer, and P. E. Poubelle. 1989. Production of monoclonal antibodies against interleukin- $1 \alpha$ and $-1 \beta$. J. Immunol. Methods. 123:193-200.

35. Chirgwin, J. M., A. E. Przybyla, R. J. MacDonald, and W. J. Rutter. 1979. Isolation of biologically active ribonucleic acid from sources enriched in ribonuclease. Biochemistry. 18:5293.

36. Clark, S. D., D. K. Kobayashi, and H. G. Welgus. 1987. Regulation of the expression of tissue inhibitor of metalloproteinases and collagenase by retinoids and glucocorticoids in human fibroblasts. J. Clin. Invest. 80:1280-1288.

37. Lotz, M., and P.-A. Guerne. 1991. Interleukin-6 induces the synthesis of tissue inhibitor of metalloproteinases-1/erythroid potentiating activity (TIMP1/EPA). J. Biol. Chem. 266:2017-2020.

38. Gianfranco, F. D. P., M. DeCarli, C. Mastromauro, R. Biagiotti, D. Macchia, P. Falagiani, M. Ricci, and S. Romagnani. 1991. Purified protein derivative of Mycobacterium tuberculosis and excretory-secretory antigen(s) of Toxocara canis expand in vitro human $T$ cells with stable and opposite (type 1 helper or type 2 helper) profile of cytokine production. J. Clin. Invest. 88:346-350. 